\title{
PROBLEMA
}

\section{HOW FAR CAN YOU GO WITH QUIETISM?}

\author{
Gerald LANG
}

\section{Resumen:}

En su trabajo Justice for Hedgehogs, Ronald Dworkin renueva y amplía sus primeras críticas a la metaética. En este artículo se estudian los principales rasgos de los argumentos anti-metaéticos que elabora Dworkin, y se analiza con detalle un número de problemas que surgen de esos argumentos. En primer lugar, se sugiere que la apreciación de Dworkin, con respecto a lo que se está haciendo en buena parte de los trabajos de carácter explicativo, está tergiversada. En segundo lugar, se sostiene que la acusación de Dworkin de que el expresivismo es auto-derrotable es inofensiva, aunque otra acusación en las mismas cercanías podría ser más efectiva. En tercer lugar, se afirma que la falta de interés de Dworkin acerca de la metafísica moral está mal orientada. Lo que realmente apoyan sus argumentos es una oposición a dejar los rehenes metafisicos a la fortuna, y no una oposición a perseguir una mayor clarificación de la metafísica moral. En esta conexión se sugiere tentativamente que Dworkin podría ser seducido por una versión particular del naturalismo.

Palabras clave:

Metaética, metafísica moral, quietismo, naturalismo, objetividad, Dworkin, Ronald. 


\title{
GERALD LANG
}

\begin{abstract}
:
Ronald Dworkin's Justice for Hedgehogs renews and amplifies his earlier attacks on metaethics. This article reviews the main lineaments of Dworkin's anti-metaethical arguments and discusses, in detail, a number of issues which arise from them. First, it is suggested that Dworkin's appraisal of what is doing most of the explanatory work in his account is largely askew. Second, it is claimed that Dworkin's allegation that expressivism is self-defeating is wide of the mark, but that another charge in the same vicinity might be more effective. Third, it is argued that Dworkin's incuriosity about moral metaphysics is misplaced. What his arguments actually support is an opposition to leaving metaphysical hostages to fortune, rather than an opposition to pursuing greater clarification about moral metaphysics. In this connection, it is tentatively suggested that Dworkin might be tempted by a certain version of naturalism.
\end{abstract}

\section{Keywords:}

Metaethics, Moral Metaphysics, Quietism, Naturalism, Objectivity, Dworkin, Ronald. 
Summary: I. Dworkin's Quietism. II. Some Smaller Worries. III. Some Bigger Worries. IV. Quietism versus QuasiRealism. V. Is Dworkin a Naturalist? VI. Conclusion.

Ronald Dworkin has always favoured a systematic approach to moral, political, and legal philosophy, and his eagerly awaited Justice for Hedgehogs aims to bring topics which are, at first blush, highly heterogeneous-they range from the character of moral and legal concepts, to the duty to provide aid to the suffering, to the nature of liberty and equality, to the requirements of justice and the proper interpretation of democracy-into a unified, holistic system. ${ }^{1}$ The title of the book, which draws upon Isaiah Berlin's interpretation of Archilochus's poem, is explained as follows:

The fox knows many things, but the hedgehog knows one big thing. Value is one big thing. ${ }^{2}$

Dworkin later speaks, less cryptically, of the

hedgehog's faith that all true values form an interlocking network, that each of our convictions about what is good or right or beautiful plays some role in supporting each of our other convictions in each of those domains of value. ${ }^{3}$

Justice for Hedgehogs promises to be an extraordinarily significant contribution to the philosophy of value. In this article, I will be concerned squarely with the arguments laid out in Parts I and II, which concern metaethics.

In Part I of Justice for Hedgehogs, Dworkin renews and amplifies a broad attack on various metaethical approaches-chiefly non-natural realism, error theory, dis-

1 Dworkin, Ronald, Justice for Hedgehogs, Cambridge, Massachusetts, Harvard University Press, 2011.

2 Ibidem, p. 1. See also Berlin, Isaiah, The Hedgehog and the Fox: An Essay on Tolstoy's View of History, London, Weidenfeld and Nicolson, 1953.

3 Dworkin, supra note 1, p. 120. 
positionalism, constructivism, and expressivism-which was originally adumbrated in Law's Empire and, at much greater length, his article 'Objectivity and Truth: You'd Better Believe It'. ${ }^{4}$ Those earlier arguments are largely intact in Justice for Hedgehogs, though the emphases are sometimes different. In any case, it is the latest formulations of the arguments I shall be chiefly concerned with.

According to one of Dworkin's sub-section headings in Chapter 3: 'Yes, Meta-Ethics Does Rest on a Mistake'. ${ }^{5}$ Now Dworkin cannot eschew metaethics completely-even the argument that traditional metaethical resources are much less significant than has usually been thought must be counted as a deliverance of metaethics. (This argument is not naturally classified as a contribution to first-order or normative ethics.) But that point is not embarrassing to Dworkin. His real contention is that there is no such thing as a metaethical grounding for normative ethics and other departments of first-order thought, such as political philosophy and applied ethics.

The article will be organized as follows. In section I, I will provide a summary of Dworkin's quietism (as well as a justification for the ascription of the term to him-he himself is resistant to it). In section II, I examine what I regard as a few comparatively minor complaints about Dworkin's arguments which have been aired in a symposium in honour of a slightly earlier incarnation of Justice for Hedgehogs, published in the Boston University Law Review. ${ }^{6}$ I believe that Dworkin's argument can withstand these particular criticisms. But there are more serious worries about his argu-

4 Dworkin, Ronald, Law's Empire, London, Fontana Press 1986, esp. pp. 76-86; and Dworkin, Ronald, 'Objectivity and Truth: You'd Better Believe It', Philosophy \& Public Affairs, 26, 1996, pp. 87-139.

5 Dworkin, supra note 1 , p. 67. There is an obvious and clearly intended echo here of Prichard, H. A., 'Does Moral Philosophy Rest On A Mistake?', Mind, 21, 1912, pp. 21-37.

6 See Schafer-Landau, Russ, 'The Possibility of Metaethics', Boston University Law Review, 90, 2010, pp. 479-96; Smith, Michael, 'Dworkin on External Skepticism', Boston University Law Review, 90, 2010, pp. 509-20; and Star, Daniel, 'Moral Skepticism for Foxes', Boston University Law Review, 90, 2010, pp. 497-508. 
ments, which will begin to emerge in section III. The remainder of the article will be largely devoted to an exploration of these more substantial difficulties. In section IV, I will consider a particularly difficult and subtle debate between Dworkin and the expressivist quasi-realist. I will then investigate, in section V, Dworkin's complaints about naturalism, and press on him the charge that he is plausibly-and, by his own lights, harmlessly-a manqué naturalist, though undoubtedly a different sort of naturalist from the versions of naturalism he considers and rejects. A brief conclusion is stated in section VI.

\section{DWORKIN's QUIETISM}

In this section I will provide a bald summary of Dworkin's leading claims, ignoring many points of detail.

It is customary to distinguish between 'first-order' moral claims, or claims which belong to the segment of philosophical ethics we call normative ethics, and 'second-order' moral claims, or claims which belong to the segment of philosophical ethics we call metaethics. On this construal, the first-order claims are concerned with questions of morality, whereas the second-order claims are concerned with questions about morality. ${ }^{7}$ But it should be noted that the first-order claims and second-order claims are often placed together in the same claims. For example, it would not be unnatural to gloss a moral statement such as 'Abortion is wrong' as 'The statement that abortion is wrong is true', or as 'It is an objective fact that abortion is wrong'.

The possibility of combining first-order and second-order claims in one and the same proposition suggests that these claims enjoy a measure of mutual relevance. Yet some writers have been prepared to assert a considerable distance between the first-order and second-order claims. J. L. Mackie, for example, who famously defended an 'error the- 
ory' of value discourse, has this to say about the relationship between them:

These first order and second order views are not merely distinct but completely independent: one could be a second order moral sceptic without being a first order one, or again the other way round. ${ }^{8}$

Mackie then goes on to argue that the second-order level of analysis will reveal that no positive first-order moral claim can be true. That is because, contrary to the implicit presuppositions of ordinary moral discourse, the world plausibly lacks the kind of objectively prescriptive and intrinsically motivating facts which could make any of those first-order positive moral claims true. However, due to the fact that first-order and second-order claims are "not merely distinct but completely independent', Mackie also seems prepared to accept that the charge of global error at the second-order level carries no implications for the fate of the claims at the first-order level. Presumably at the first-order level, then, claims will continue to be held to be true or false on grounds which will be familiar to practitioners of normative ethics - that is, to all of us who have ever got into an argument about a moral issue.

Dworkin profoundly distrusts this separation between first-order and second-order moral discourse:

If I am right ... that there are no non-evaluative, second-order, meta-ethical truths about value then we cannot believe either that value judgments are true when they match special moral entities or that they cannot be true because there are no special entities for them to match. Value judgments are true, when they are true, not in virtue of any matching but in virtue of the substantive case that can be made for them. The moral realm is the realm of argument not brute, raw fact. 9

8 Mackie, J. L., Ethics: Inventing Right and Wrong, London, Penguin, 1977, p. 16 .

9 Ibidem, p. 11. 
What, then, is the function of the second-order claims (or the 'further claims', as Dworkin sometimes refers to them)? ${ }^{10}$ How is their interaction with the first-order claims to be understood? The function of the second-order claims, according to Dworkin, is chiefly to emphasize the content of the first-order claims - to assert the speaker's view that the truth of those first-order claims is not a matter of mere taste, or that the truth of the first-order claim is not taken to depend on any ongoing attitude which the speaker or anyone else bears to it, so that the claim would continue to be true (if it is true) even if nobody thought it was true. ${ }^{11}$ In what follows, I shall say that Dworkin supplies a 'continuity reading' of the further claims, as opposed to Mackie's 'discontinuity reading' of them.

The two passages above convey the essence of Dworkin's position. Now I want to fill out the picture a little more, and to indicate some of the friends and enemies which Dworkin relies upon and duels with, respectively, in Part I of Justice for Hedgehogs. These encounters will be described in fuller detail in the sections to come.

Throughout Part I, Dworkin places special emphasis on what he calls 'Hume's Principle', which

holds that no series of propositions about how the world is, as a matter of scientific or metaphysical fact, can provide a successful case on its own-without some value judgment hidden in the interstices-for any conclusion about what ought to be the case. ${ }^{12}$

Dworkin is taking inspiration here from Hume's famous passage forbidding the coupling of 'ought' claims and 'is' claims:

In every system of morality, which I have hitherto met with ... the author proceeds for some time in the ordinary way of

10 Ibidem, p. $53 \mathrm{ff}$.

11 Ibidem, p. 54.

12 Ibidem, p. 44. 
reasoning ... when of a sudden I am surpriz'd to find, that instead of the usual copulations of propositions, is, and is not, I meet with no proposition that is not connected with an ought, or an ought not. This change is imperceptible; but is, however, of the last consequence. For as this ought, or ought not, expresses some new relation or affirmation, 'tis necessary that it shou'd be observ'd and explain'd; and at the same time that a reason should be given, for what seems altogether inconceivable, how this new relation can be a deduction from others, which are entirely different from it. ${ }^{13}$

Dworkin's enthusiastic recruitment of Hume under his objectivist banner may seem initially surprising. Hume has traditionally been interpreted to pose a challenge to ethicists with objectivist aspirations. This is because the inability to recover an 'ought' from a series of 'is' claims is taken to put pressure on the descriptivist framework which is normally assumed by defenders of moral objectivity. ${ }^{14}$ But Dworkin is untroubled by this, because what he wishes to recover from Hume is the different lesson that morality is not answerable to any grounding in non-moral fact. The descriptivist framework which moral phenomenology suggests to us can therefore be taken for granted. We do not have to worry about its impropriety on the grounds that the world has failed to cooperate with the demands of moral discourse. In the relevant sense, there are no external hurdles which moral discourse has to clear, which means that moral discourse is answerable only to the standards internal to it. Thus Hume's Principle helps to liberate us from the Gibraltar of all mental blocks: that something other than value must underwrite value if we are to take value seriously'. ${ }^{15}$

13 Hume, David, A Treatise of Human Nature, 2nd. ed., edited by Selby-Bigge, L. H.. and Nidditch, P. H., Oxford, Clarendon Press (1978, p. 469); cited in Dworkin, supra note 1, pp. 425-426 (at n. 6).

14 There is also, of course, Hume's apparent insistence that moral judgments express passions rather than beliefs: see section IV.

15 Dworkin, supra note 1, pp. 16-17. 
Hume's Principle allows us, as a corollary, to distinguish between 'internal scepticism' and 'external scepticism'. ${ }^{16}$ Internal scepticism is scepticism about morality which does not 'go all the way down': it rejects certain positive moral claims on the basis of other positive moral claims. Internal sceptical challenges may take a global form. For example, pessimism about free will and responsibility may generate scepticism about most of our positive moral claims, but the resulting scepticism will be internal or engaged, because it is derived from the substantive moral principle that moral claims can be true only if they hold for agents who can be responsibly sensitive to them. Another example of a global internal sceptical challenge is provided by the view that moral claims can be true only if they are the product of a divine will. Again, this is an internal rather than an external challenge because it proceeds from a substantive moral principle. Hence internal sceptical challenges do not violate Hume's Principle. They do not pretend to issue 'ought' claims from a collection of purely 'is' claims.

Dworkin is not concerned to rebut internal sceptical challenges in the early parts of Justice for Hedgehogs; he engages with them only in the later parts of the book. ${ }^{17} \mathrm{Ex}-$ ternal sceptical challenges, by contrast, do violate Hume's Principle, and it is Dworkin's aim in Part I to reject these challenges root and branch. These are forms of scepticism which profess to go 'all the way down'. They seek to disprove or undermine morality, or else what morality appears to us to be, from somewhere outside it: by claiming, for example, that the world lacks the kind of metaphysical entities which could confer truth upon any of our first-order moral claims.

External scepticism comes in two varieties: error scepticism and status scepticism. The former tells us that morality is a 'misconceived enterprise', while the latter tells us that

16 Ibidem, pp. 30-32.

17 I will return, however, to the interpretation of the global internal sceptical challenges in section III. 
morality is a 'misunderstood enterprise'. 18 Error scepticism claims that, according to 'value-neutral metaphysics', ${ }^{19}$ all our positive moral claims are false. Thus an error sceptic

might read the ordinary view [of morality] as assuming that moral entities exist: that the universe contains not only quarks, mesons and other very small physical particles but also what I called morons, special particles whose configuration might make it true that people should not torture babies and that optional military invasions seeking regime change are immoral. ${ }^{20}$

Mackie provides us with a prominent example of an external error sceptic.

Status scepticism, by contrast, 'encourages us to keep our convictions and give up only bad metaphysics'. ${ }^{21}$ It does that by interpreting the first-order claims in a way which allows them to avoid the metaphysical disappointment that would otherwise ensue from the realization that the world contains no morons. On this view, the first-order claims are construed in a non-factualist way, as expressions of emotions or attitudes. If they are construed in this way, then the first-order claims are neither true nor false. But that, of course, offends against moral phenomenology, as Dworkin notes. (More sophisticated versions of expressivism do provide for talk of truth and objectivity: these versions will be examined in section IV.)

Connected to the presuppositions of external error scepticism are what Dworkin calls the 'causal impact hypothesis', and the 'causal dependence hypothesis'. ${ }^{22}$ According to the causal impact hypothesis, 'moral facts can cause people to form moral convictions that match those moral facts'. ${ }^{23}$ And according to the causal dependence hypothesis, "unless the

18 Dworkin, supra note 1, p. 32.

19 Idem.

20 Idem.

21 Ibidem, p. 52.

22 Ibidem, p. 70.

23 Idem. 
causal impact hypothesis is true, people can have no sound reason to think that any of their moral judgments is a correct report of moral truth'. ${ }^{24}$ Both these hypotheses, on Dworkin's view, are implicitly wedded to the same presuppositions as external error scepticism. Defenders of them see moral truth as consisting in correspondence with something brutely metaphysical. But it is not just error sceptics who embrace these two hypotheses. They are also upheld by those realists who wish to vouch for the genuineness of moral facts and properties, such as the so-called 'Cornell' realists. And Cornell realists' attachment to the causal impact hypothesis and the causal dependence hypothesis therefore makes this brand of moral objectivity objectionable, even though these realists are no more prepared to affirm the existence of morons than Dworkin is.

Where, finally, is Dworkin to be located in metaethical territory? He says he is resistant to the various pigeonholes which have emerged in recent metaethical discourse, and is resistant, in particular, to the label of 'quietism'. ${ }^{25} \mathrm{He}$ remarks that the term 'quietism' suggests 'a dirty secret kept dark'. ${ }^{26}$ But the ascription of a term cannot be properly refused simply because it has generated unwelcome associations in some quarters. Though non-quietists may have unflattering things to say about quietism, presumably quietists will be prepared to assemble a more enthusiastic case for it. If the label appears to fit, the strategy should be to accept it and disparage those associations, rather than to resist the label and insist that one is entitled to stand above the fray and remain loftily unclassifiable. And the label does indeed appear to fit. Dworkin contends that the integrity of first-order moral argument is not dependent on any metaphysical grounding; that the success or failure of first-order argument is not dependent on any news appearing on the metaethical front. Moral discourse is therefore

\footnotetext{
24 Idem.

25 Ibidem, p. 11.

26 Ibidem, p. 25.
} 
answerable only to the standards which are internal to it. But this is just the kind of position which, in general, quietism is taken to designate. So, although he may deny it, Dworkin is a quietist. But that should not trouble him. As I see it, to insist that he is a quietist is not to saddle him with toxic debts that some more generous or sensitive characterization of him might have hoped to avoid. ${ }^{27}$

\section{Some SMaller WorRieS}

In this section I will deal with (as I regard them) three comparatively minor complaints about Dworkin's arguments proposed by Russ Schafer-Landau, Michael Smith, and Daniel Star in the recent published symposium on Justice for Hedgehogs. ${ }^{28}$

First, these authors all take Dworkin to task for characterizing the external error sceptic as providing for the existence of permissibility as a genuine characteristic of actions. They disagree: error sceptics do not provide for permissibility any more than they provide for the properties which are subsumed under the other normative categories. All of these normative properties are deemed not to exist by the error sceptic. So Dworkin misunderstands what error

27 One further note on the structure of Dworkin's commitments: it seems to me that his criticism, in Dworkin 'Objectivity and Truth', supra note 4, pp. 106-7, of Crispin Wright's 'cognitive command' criterion of realism, where disagreement between parties must be construed in such a way as to support the ascription of cognitive or informational error to at least one of those parties, is wide of the mark. Dworkin thinks Wright's view is faulty because the mere attribution of cognitive or informational error cannot make any useful contribution to the resolution of any given first-order dispute. But Dworkin's own view of the function of the further claims would surely also be inert in that particular role: the Dworkinian construal of the further claims could amount only to table-thumping. It is Wright's 'width of cosmological role' criterion, not the cognitive command criterion, which Dworkin probably ought to regard with suspicion; as I see it, the cognitive command criterion threatens no injury to quietism. For Wright's views, see Wright, Crispin, Truth and Objectivity, London, Harvard University Press, 1992.

28 I am not in a position, naturally, to be able to offer an exhaustive evaluation of their respective arguments. (Such an approach might be unwise for an independent reason: their criticisms are directed at an earlier draft of Justice for Hedgehogs.) 
sceptics are up to, and fails to award logical space to a position which denies impermissibility, but also fails to affirm permissibility. ${ }^{29}$ I shall call this the No Permissibility Argument.

The No Permissibility Argument strikes me as unfair. Dworkin's real point, surely, and a point he makes repeatedly in his work, is that we simply don't know what to make of arguments which purport to show that $X$ is not, after all, impermissible, if it does not then follow that $X$ is permissible. ${ }^{30}$ Why don't we know what to make of such arguments? The relevant reasoning is downstream from Dworkin's main argument that moral conclusions, or moral claims, can only be affected by considerations which seem pertinent to the conduct of first-order moral argument. ${ }^{31}$ Now perhaps Dworkin's emphasis on this Pertinence Condition, as I am going to refer to it, does not establish the conclusions he favours, but that will be a separate failing from the failings allegedly established by the No Permissibility Argument. The No Permissibility Argument does not, in and by itself, expose a chink in Dworkin's armour, and it is ungenerous to accuse him of logical obtuseness. Confronted with the reply that the error sceptic is attempting to draw attention to a presupposition failure of moral discourse, from which it will follow that $X$ is neither permissible nor impermissible, Dworkin can simply refuse to admit the possibility of presupposition failures which reflect brute metaphysical truths, since the supposed relevance of those truths cannot be reconciled with the Pertinence Condition. The ball will be then in the error sceptic's court, not Dworkin's.

Two further, and related, problems are concerned with Hume's Principle. The first of these alleged problems proceeds from Dworkin's claim that wholly non-moral meta-

29 Schafer-Landau, supra note 6, pp. 490-491; Smith, supra note 6, pp. 512-513; and Star, supra note 6, pp. 499-500.

30 Dworkin supra note 1, pp. 42-43; cf. Dworkin, 'Objectivity and Truth', supra note 4, p. 95 .

31 In my view, it is this principle, not Hume's Principle, which Dworkin is really relying upon: see the next section. 
physical properties and facts cannot vindicate moral claims. Schafer-Landau and Star offer the reply that nonmoral metaphysical facts might nonetheless undermine moral claims, even if they cannot vindicate them. ${ }^{32}$ I will refer to this argument as the Undermining Argument. The third problem is derived from Dworkin's supposed inattention to the fact that, while Hume forbids deductive inference from 'is' claims to 'ought' claims, he is hospitable to non-deductive traffic between them. I shall call this argument the Non-Deductive Argument. ${ }^{33}$

Like the No Permissibility Argument, I think these two further arguments are ineffective. ${ }^{34}$ I discuss them in turn. Consider, first, the counter-examples offered by SchaferLandau and Star in illustration of the Undermining Argument. Schafer-Landau gives the example of someone-let us call him Jones-who is suspected of participating in the armed robbery of a bank. Schafer-Landau then stipulates that, while the suspicion of criminality against Jones cannot be vindicated by Jones' location in the bank at the time of the robbery-he might, after all, have been merely an innocent onlooker-the suspicion of his guilt will be undermined if it turns out that Jones was definitely elsewhere. Star's example concerns the approach of an asteroid towards earth, which an agent is physically powerless to prevent. Given the application of the 'ought implies can' principle-a principle which is not itself a first-order claim-Star concludes that we can properly conclude that it is not the case that this agent ought to stop the asteroid.

To what extent are these cases analogous to the moral case? They seem utterly disanalogous to me. In SchaferLandau's example, Jones' presence in the bank at the time of the robbery is a necessary but not sufficient condition of his guilt; facts about his whereabouts at the time of the robbery can undermine the case against him, but they can-

32 Schafer-Landau, supra note 6, p. 485, and Star, supra note 6, p. 502.

33 Schafer-Landau, supra note 6, pp. 485-486.

34 The real problem with Hume's Principle is explored in the next section. 
not vindicate the case against him. His guilt can only be established by further investigation. Dworkin's analogous claim is that the presence of morons cannot vindicate moral claims; so, by analogy, he must have failed to pay attention to the possibility that the absence of morons can nonetheless undermine moral claims. Now even though the 'vindication' claim is logically distinct from the 'undermining' claim, the arguments Dworkin advances against the vindication claim plausibly encompass the undermining claim as well. If the existence of a brute metaphysical fact, $M$, cannot vindicate a moral claim, $C$, for the reasons Dworkin gives, then it will follow that the absence of $M$ cannot undermine $C$. Dworkin is clear throughout that he is completely uninterested in the existence of morons. They could confer no justification on moral claims at all, whether that confirmation took a final or merely intermediate form.

The same points can be applied to Star's asteroid case. The absence of morons cannot undermine the probity of some given first-order moral claim any more than the presence of morons could uphold the probity of that first-order claim. Unlike other kinds of non-moral fact, such as facts bearing on one's physical ability to make any difference to the trajectory of an asteroid, facts about morons are simply not the kind of facts which could make any difference to the truth or defensibility of a first-order claim. ${ }^{35}$ In short, Dworkin is not undermined by the Undermining Argument.

The Non-Deductive Argument also seems weak. Presumably Dworkin's invocation of Hume is not slavish. Though Hume himself may have been hospitable to non-deductive traffic between 'is' claims and 'ought' claims, Dworkin is entitled to remain untroubled by a possible accumulation of abductive evidence for the untenability of first-order moral

35 Dworkin counts the 'ought implies can' principle as an internal first-order principle (albeit an abstract one), rather than as an external principle: Dworkin, supra note 1, p. 428 (at n. 5). I suspect he is right about that as well. But the important point is that Dworkin can accommodate the moral relevance of indisputably non-moral facts without having to concede that morons may also be morally relevant to the assessment of first-order moral claims. 
claims in the light of the non-existence of special moral properties which could confer truth upon those claims. How would such arguments get going? What cumulative argumentative forces could push us in the direction of any conclusion which declared itself to be troubled by the absence of morons? Once again, Dworkin seems dialectically entitled to stay in his corner and see what the opposition has to say next. I doubt that he will be too worried.

\section{SOME BIGGER WORRIES}

Despite Dworkin's ability to withstand these minor challenges, he is vulnerable to some other challenges. Most importantly, though he claims that metaethics rests on a mistake, the arguments Dworkin deploys seem poorly placed to shut down at least some metaethical lines of investigation. Schafer-Landau usefully lists a number of familiar metaethical questions in his commentary on Dworkin, which I reproduce here in full: 36

(A) Are moral standards eternally true?

(B) Are value judgments intrinsically and necessarily motivating?

(C) Do moral requirements entail categorical reasons for action?

(D) What is the nature of a moral property?

(E) What is the modal status of the supervenience relation that obtains between moral and non-moral features?

(F) Why think that a belief's having emerged from equilibrium epistemology as any evidence of its truth?

(G) Physical laws are true generalizations of the nature and workings of physical objects and forces. Moral laws are not like this. What, then, makes all true moral laws true?

Schafer-Landau believes that these various questions cannot be plausibly held to be improper, or badly formed, 
or uninteresting, or unimportant. I agree with him. And these questions are all broadly conceptual, rather than substantive. Though they may ultimately arise from the very general features exhibited by first-order moral discourse, engagement with them does not commit us to any direct involvement in first-order arguments.

To what extent, then, is Dworkin prepared to engage with these questions, and on what terms? As things stand, he has far too little to say about (D) and (E). This is, I think, the most serious omission from his discussion. But the damage is not catastrophic. I shall have more to say about these particular issues in section $\mathrm{V}$, when $\mathrm{I}$ discuss Dworkin's relationship with naturalism. (It is closer than he might think.) By contrast, Dworkin has a fair bit to say about (B) and (C): I shall discuss these particular issues in section IV. As for (A), (F) and (G), Dworkin is prepared to count them as first-order or internal challenges, albeit very abstract first-order challenges. He is insistent, first, that a theory of moral epistemology is really a theory of responsibility: when we participate in moral argument, we have the responsibility to reason in ways which display, in as much luminous detail as we can muster, the various evaluative connections between the various judgments we have arrived at. ${ }^{37} \mathrm{He}$ also insists, as we know, that we have no business worrying about the correspondence of our moral conclusions with brute metaphysical facts about the world. Now presumably there are ways of taking $(\mathrm{A}),(\mathrm{F})$, and $(\mathrm{G})$ which do commit us to worrying about the reality of this metaphysical correspondence. Dworkin is, I believe, within his rights to remain deaf to such appeals. I will thus say no more about these particular questions here.

Still, Dworkin's frequent habit of recasting supposedly 'external' questions as 'internal' questions represents less of an achievement than he thinks. The remaining part of this section will investigate why that is so. Dworkin holds that there are no defensible external sceptical strategies, but 
that there are global internal sceptical challenges. As indicated earlier, one of Dworkin's examples is supplied by what I will call the atheist's challenge, which holds that no substantive first-order moral claim is true unless that proposition has been willed by a wholly good, all-powerful god. This is supposed to be an internal challenge, albeit a global internal challenge, because it proceeds from a recognizably substantive moral claim - the very claim which asserts that moral claims are true only if they display this dependence on a divine will. ${ }^{38}$

The problem with this line of argument is that it reveals the division between internal and external scepticism to be troublingly porous, or leaky. Compare the atheist's challenge with this challenge, which we can call the non-naturalist challenge:

There are no moral properties, no moral reasons for and against different courses of action, because there are no non-natural properties which can confer truth upon any of those claims.

Dworkin, of course, will insist that the non-naturalist challenge represents an external sceptical challenge. That is because it rests upon a metaphysical thesis which is unengaged with first-order moral argument. But it is fairly easy to restate the non-naturalist challenge in a way which discloses it as an internal sceptical challenge. Consider the following non-naturalist advice principle:

No moral claim is true unless it is made true by the existence of a truth-making non-natural property, and so no moral claim should be taken as true unless we are in the position to vouch for the existence of the relevant non-natural property.

The non-naturalist advice principle bridges the realm of the moral with the realm of the metaphysical. It is also a 
substantive moral principle. It purports to offer practical advice, albeit highly refined and abstract practical advice, for those who conduct ordinary moral arguments. In this sense, it is comparable to the atheist's challenge. 39

You may think that the non-naturalist advice principle is implausible, even preposterous. ${ }^{40}$ But that is beside the point. The plain fact of the matter is that, as a substantive moral principle, it does not offend against Hume's Principle. If it does not offend against Hume's Principle, then the division between internal and external scepticism will, in turn, seem toothless. Any sceptical challenge which Dworkin would prefer to consign to the external camp can be easily re-described in terms which reveal it to be a member of the internal camp.

When all is said and done, then, Hume's Principle, and the division between internal and external scepticism, do rather little work for Dworkin. Despite his rhetoric, these do not provide him with any live ammunition. I will call this line of argument, which has aimed to show that (what Dworkin would prefer to describe as) external sceptical challenges can be re-described as internal sceptical challenges, the Leakage Worry.

My drawing attention to the Leakage Worry is not intended to function as a refutation of Dworkin, or to pretend that he would be unable to muster a strong case against the non-naturalist advice principle. It is intended primarily to get clear on what is doing the heavy lifting in his system. I think this must be provided by his claim that the proper interpretation of the further claims needs to display their pertinence to the first-order claims. It is Dworkin's Perti-

39 Consider the fact that many participants in first-order moral arguments will be utterly uninterested (qua first-order moral participants) in theistic groundings for morality. That does not stop the atheist's challenge from being properly classified as an internal challenge. But if that is so, then the fact that many or most participants in first-order moral arguments will be utterly uninterested (qua first-order moral participants) in metaphysical groundings for morality is similarly incapable of stopping the non-naturalist challenge (with a little tweaking) from being classifiable as an internal challenge.

40 As do I, in fact: see the discussion of the Hostages to Fortune View in section V. 
nence Condition which provides his strongest argument against external error scepticism.

Still, how far can we really get with the Pertinence Condition? We seem, at this stage of the dialectic, to be squarely dependent on what the ordinary participants in first-order moral discourse take to be pertinent to their concerns. That does not present us with any sharp tools for distinguishing between worries which can be properly ignored, and worries which tend to be improperly (though perhaps understandably) discounted in the heat of the moment. Even so, the Pertinence Condition is far from completely flaccid: the more outré versions of the further claims which are clearly unengaged from the first-order claims still look deeply unappetizing. But a danger emerges at this point, which is that Dworkin's commitment to the Pertinence Condition is rather similar to that of a rival approach, namely, expressivism. I shall examine the relationship between quietism and expressivism in the next section.

\section{QUIETISM VERSUS QUASI-REALISM}

It is hard to follow the complicated debate between Dworkin and Simon Blackburn without being reminded of the old adage about keeping your friends close, but your enemies closer. As Dworkin remarks, in his reply (in the BEARS online symposium) to Blackburn's commentary on his 'Objectivity and Truth': 'He says that I am dead wrong, and besides he said it first'. ${ }^{41}$

The difficulties here stem principally from the significant commitments which Dworkin and Blackburn agree on. First, they both deny the availability or the relevance of external metaphysical groundings for morality. Second, they

41 See Dworkin, 'Reply to Blackburn', BEARS symposium on Dworkin 'Objectivity and Truth', supra note 4: online at $h t t p: / / w w w . b r o w n . e d u / D e p a r t m e n t s / P h i$ losophy/bears/symp-dworkin.html, 1997; Dworkin is here replying to Blackburn, 'Comment on Dworkin', BEARS symposium, online at http://www.brown.edu/De partments/Philosophy/bears/symp-dworkin.html. 
both adopt a continuity reading of the further claims, where the further claims simply emphasize or qualify the content of first-order claims, thus allowing talk of truth and objectivity to be properly attributable to first-order claims. ${ }^{42}$ So how - if at all- are quietism and expressivist quasi-realism supposed to differ?

The chief difference between them, as I see it, is that Dworkin is a descriptivist all the way down. The first-order claims are straightforwardly descriptive claims: they are in the business of describing moral reality. For Dworkin, then, the descriptive function of the first-order claims is not under pressure at any point. The further claims testify to the ambition of descriptive adequacy, but not in any way which commits those first-order claims to the more particular ambition of having moron-type truth-makers. Blackburn, by contrast, aims to show that, in the first instance, first-order claims should be interpreted as expressions of conative attitudes. ${ }^{43}$ When the full apparatus for the correction, criticism, and refinement of attitudes is disclosed, this will create an opportunity for the further claims to accentuate the content of first-order claims without having to be interpreted as vouching for any heavy-duty metaphysical correspondence between the first-order claims and the world; and, by this stage, the first-order claims will also turn out to function like claims in a familiar assertoric, descriptivist discourse. ${ }^{44}$ But Blackburn thinks that we need to proceed in this roundabout manner in order to discharge explanatory debts which would otherwise go unsatisfied.45 On Blackburn's view, in effect, Dworkin simply helps himself to

42 Third - it seems fair to add as a more minor point of comparison - they both seem rather tetchy about having metaethical labels attached to their theories, which doesn't help with the interpreter's task of keeping the score between them.

43 For a particularly revealing discussion, see Blackburn, Simon, 'How to be an Ethical Anti-Realist', in his Essays on Quasi-Realism, Oxford: Oxford University Press, (1993, esp. pp. 168-71).

44 See Blackburn, Simon, Ruling Passions: A Theory of Practical Reasoning, Oxford, Oxford University Press, 1998, and several of the essays in Part II of Blackburn, Essays on Quasi-Realism, supra note 44.

45 See Blackburn, 'Comment on Dworkin', supra note 42. 
the descriptivist framework without having earned the right to do so.

There are really two questions to pursue here. First, we need to inquire into the charge that Dworkin has illegitimately and lazily helped himself to conclusions he has not bothered to argue for. Second, we need to examine the particular charge laid against Blackburn that his account is in some manner self-annihilating. I will consider these questions in turn.

Has Dworkin enjoyed all the benefits of theft over honest toil? I don't think so, though we will not be in the position to give him a full bill of health until the conclusion of the article. ${ }^{46}$ Moral discourse has a descriptivist character. By itself, that is not enough to secure moral objectivity: to claim otherwise is to risk mistaking 'resonance for reference', as Williams tellingly puts it. ${ }^{47}$ But the gravity of the charge against Dworkin all depends on the challenges which lie in wait for the aspiring objectivist. ${ }^{48}$ One worry is likely to be metaphysical: though first-order moral claims may aim at truth, the world does not satisfy our expectations in this regard. It seems to me that Dworkin basically says enough to allay this worry. We do not think that morons function as the truth-makers of our first-order claims. However, he is unacceptably reticent about the nature of moral properties. ${ }^{49} \mathrm{I}$ explore this issue in section $\mathrm{V}$.

Another set of worries concern the action-guiding or practical nature of moral judgments. One of these worries

46 Even then, we will not be in a position to fully vouch for the success of his programme, as everything will all depend on the success of his account as a whole. See my remarks in the concluding section.

47 Williams, Bernard, 'Ethics and the Fabric of the World', in his Making Sense of Humanity, Cambridge, Cambridge University Press, (1995, p. 177).

48 This is a point particularly emphasized by Dworkin, 'Reply to Zangwill', BEARS symposium: online at http://www.brown.edu/Departments/Philosophy/ bears/symp-dworkin.html, 1997, which responds to Zangwill, Nick, 'Comment on Dworkin', BEARS symposium: online at http://www.brown.edu/Depart ments/Phi losophy/bears/symp-dworkin.html, 1997.

49 As indicated above, Schafer-Landau's questions (D) and (E) seem particularly pertinent in this connection: see section III, above. 
concerns moral reasons: are they really as categorical as they pretend to be? ${ }^{50}$ Another worry concerns motivation: if the making of moral judgments generates appropriate motivational energy in the agents who make them, then won't the relevant mental states have the wrong direction of fit to redeem the descriptivist phenomenology?

With respect to reasons for action, Dworkin displays overt sympathy for the categorical nature of moral reasons in Part I, 51 but most of the relevant discussion is tendered out to the later parts of the book, where he develops, and then, applies, a quasi-Kantian framework which places particular emphasis on dignity and self-respect. ${ }^{52}$ These parts of the discussion lie beyond my remit.

Now I turn briefly to motivation. Dworkin is perfectly aware of the intellectual pressures created by the close connection between moral judgment and motivation. That inclines some philosophers - most notably, expressivistsinspired by different Humean passages, to claim that moral judgments express mental states with a conative or worldto-mind direction of fit, rather than mental states with a cognitive or mind-to-world direction of fit. But if that is so, moral judgments will not be truth-apt, and will not be amenable to the quietist account of them.

The claim that the connection between a moral judgment and appropriate motivation is an internal or conceptual one goes by the name of 'internalism about motivation'. Some objectivists, such as the Cornell realists, are inclined to reject internalism about motivation. But that is not Dworkin's way. Dworkin seems inclined to hold on to both internalism and cognitivism. So how does he propose to do this?

Dworkin offers two salient arguments for the consistency of internalism and cognitivism: first, he takes issues with

50 The belief that moral reasons are not categorical was, of course, of massive importance to Mackie's error theory. See also Schafer-Landau, supra note 6, pp. 492-493.

51 Ibidem, pp. 49-51.

52 Ibidem, esp. ch. 11. 
the claim that the 'directions of fit' argument establishes that world-to-mind and mind-to-world directions of fit cannot be combined in one and the same mental state; and second, he suggests that an agent's failure to be appropriately motivated by a moral judgment places severe pressure on the proper attribution to her of that very judgment. ${ }^{53}$ Though Dworkin's defence of these claims could certainly do with some amplification, it seems to me that he is basically on the right lines.

In short, and depending, in part, on his ability to make progress on the question of what moral properties are, Dworkin can plead innocence against Blackburn's charge.

Now I turn to the charges Dworkin makes against Blackburn. Dworkin alleges that Blackburn's 'strategy swallows itself like the Cheshire Cat leaving only a smile behind'.54 To explain what this striking charge amounts to, I will step back and briefly consider Dworkin's general treatment of status scepticism. ${ }^{55}$

Dworkin's argument against status scepticism is divided into two parts. ${ }^{56}$ First, he attacks what he calls 'speech act' expressivism, and second, he attacks a more sophisticated variant of expressivism which he labels the 'two language games' version of expressivism. These variants of expressivism take opposed views on the relationship between firstorder claims and the further claims which testify to the truth or objectivity of those first-order claims.

53 Ibidem, pp. 48-49, and 56-58; see also Dworkin, 'Reply to Blackburn', supra note 42 .

54 Dworkin, supra note 1, p. 63; cf. Dworkin, 'Objectivity and Truth', supra note 4, p. 112 .

55 Dworkin's treatment does not address certain forms of expressivism, such as the theory of 'cognitivist expressivism' recently developed by Horgan, Terry, and Timmons, Mark, 'Non-Descriptivist Cognitivism: Framework for a New Metaethic', in Foundations of Ethics: An Anthology, edited by Schafer-Landau, R., and Cuneo, T., Oxford: Blackwell, 2006. For helpful commentary on the proliferation of options in this area, see Dreier, James, 'Metaethics and the Problem of Creeping Minimalism', Philosophical Perspectives, 18, 2004, pp. 23-44.

56 Dworkin, supra note 1, pp. 52-63. 
According to the 'speech act' version, the further claims are discontinuous from the first-order claims: they are to be interpreted in an external manner. Because, on the expressivist view, there is no possibility of any metaphysical vindication of the first-order claims, the only way of saving moral discourse from a charge of massive error is to re-interpret those first-order claims as expressions of conative or non-cognitive attitudes towards certain states of affairs. ${ }^{57}$ Dworkin thinks this expressivist 'speech act' re-interpretation of the first-order claims is open to two charges: first, it is phenomenologically unconvincing, because avowing moral commitments plausibly amount to more than simply letting off steam or projecting non-cognitive attitudes; and second, it is needless, since the further claims did not have to be interpreted in the first place as offering morality any external metaphysical vindication.

Since few expressivists defend the speech act version these days, I will move on immediately to the two language games version of expressivism, where we find Blackburn and other writers, such as Allan Gibbard.58 The main difference between the language games version and the speech act version is that the language games version is supposed to supply a reading of the further claims where they are continuous with the first-order claims, offering emphasis, rather than metaphysical gravitas. Both the first-order claims and the further claims belong to the 'morality game', and the expressivism, which asserts that moral discourse must be interpreted as projections on to a value-free world, belongs to the distinct 'philosophy game'.

So what exposes the language games version to Dworkin's 'Cheshire Cat' satire? Dworkin's dialectic is complicated, but it seems to me that his argument supports two possible versions of the charge, both of them ultimately

57 Of course, this starting-point will also accommodate (for some tastes) the action-guiding character of moral judgments.

58 See, for example, Gibbard, Allan, Thinking How To Live, London: Harvard University Press, 2003. The labels are squarely Dworkin's-they are not brandished by either Blackburn or Gibbard. 
proceeding from the continuity reading of the further claims which the sophisticated expressivist, no less than the quietist, has supposedly secured.

Here is one version of the problem: if the talk of truth and objectivity recorded by the further claims can be truly appended to the first-order claims, then we lack a justification for characterizing the first-order claims as anything other than they appear to be: namely, assertoric, truth-apt statements. Precisely because Blackburn claims to be able to make room for the expression of the further claims, his expressivist, non-cognitivist construal of the first-order claims is immediately undermined, and expressivism will be 'a bust from the start'. ${ }^{5}$ Non-cognitivist attitudes are not truth-apt, and cannot therefore be true.

Blackburn's preferred answer to this charge, I should think, will be that once the full evaluative apparatus of correction, criticism and refinement is securely in place, the first-order claims are no longer simple expressions of non-cognitive attitude which are such as to escape classification as truth-apt. They are now more complicated attitudes, which behave in ways which make them, to all intents and purposes, truth-apt.

For the purposes of argument, I am prepared to grant Blackburn this reply. Dworkin is not finished yet. Here is another version of the problem: since Blackburn claims that he has managed to construe the further claims in a way which makes them continuous with the first-order claims, he has undermined any reason to think that we ever needed to construe the first-order claims in such a way as to save them from exposure to a heavy-duty construal of the further claims. If we can avoid interpreting the further claims in the heavy-duty, metaphysical-gravitas-conferring way by interpreting them as Blackburn wishes to construe them, then the motivation for re-interpreting the first-order claims as-at least originally-non-cognitive attitudes will be undermined. The descriptivist 'morality game' will now

59 Dworkin, supra note 1, p. 52. 
take up all the available space, and there will be nothing for the 'philosophy game' to do; there will be no world, as Dworkin puts it, for the status sceptic to bustle in. 60

How powerful is this argument? At least two points need to be made on Blackburn's behalf. First, and just to be clear, Blackburn cannot be reasonably accused of siding with a heavy-duty construal of the further claims and also siding with a 'light touch' construal of them, where the further claims offer emphasis rather than correspondence. After all, he offers the light touch construal of the further claims in order to escape from the heavy-duty construal of them. So he is not open to the charge of having his cake and eating it too; there is no charge of inconsistency or of divided loyalties to level against him. Second, Blackburn can point out that his light touch construal of the further claims is facilitated by a construal of the first-order claims according to which they started out life as nothing grander than simple non-cognitive attitudes. They are not simple noncognitive attitudes at the end of the evaluative story, but that is precisely what they are at the start of the story; and it is those humble, conceptually hygienic origins which enable Blackburn to make good on his project of explaining the cognitive shape of moral discourse. ${ }^{61}$

These points shield Blackburn from the immediate charge levied against him by Dworkin. His account is not self-annihilating or self-defeating. But Blackburn is still exposed to a charge lurking somewhere in the same vicinity. The charge may be put like this: if Blackburn can construe the further claims in a light touch way, then so can Dworkin. But if the further claims are thus construed, then there is nothing to stop those further claims from partnering a straightforwardly descriptivist construal of the

60 Ibidem, p. 62.

61 I lack the space here to explore how the sophisticated expressivist fares against the two charges most frequently levied against it: the Frege-Geach problem and the mind-dependence problem. (The fact that Blackburn can supply a continuity reading of the further claims does something to address the mind-dependence problem-but not, I think, everything.) 
first-order claims, and there will have been no need to insist that the first-order claims started off life as simply expressions of non-cognitive attitudes. We will have been furnished with descriptivist resources from top to bottom, just as Dworkin contends, and Blackburn's account, in turn, will have come to seem inefficient, or pointlessly circuitous; his detour through non-cognitive mental states will have served no real purpose.

I believe that the charge of circuitousness against Blackburn has force. But two matters ought to give us pause at this point. First, Dworkin is not as candid as he ought to be about the nuts and bolts of the descriptivist picture he has assembled. I will discuss that particular matter in the next section. Second, Blackburn can say that his construal of the first-order claims as-at least at some point in the story-non-cognitive helps to account for the close connection between moral judgment and motivation. How important an advantage this amounts to depends on how the relevant motivational data is handled. If it is thought that Dworkin's alternative treatment of this data is preferable to Blackburn's-see the sketch of his account given above-then Blackburn will lack a convincing rationale for foisting a conative interpretation on to the mental states which constitute moral judgments.

I conclude this section by considering Michael Smith's attempt to rescue quasi-realism from Dworkinian criticisms. ${ }^{62}$ Smith argues that the status sceptic can find conceptual room to meet both the Pertinence Condition (whereby the further claims are given a continuity reading and the first-order claims are thus permitted to be objectively true) and the 'Independence Condition' (according to which the further claims retain aspects of a discontinuity reading and the first-order claims can thus be unmasked

62 Smith, supra note 6, pp. 517-520. Schafer-Landau, supra note 6, pp. 493494, makes somewhat related remarks about the possibility of showing that morality might be 'second-rate' without having to succumb to an error theory. 
as objectively deficient). ${ }^{63}$ Smith's essential point is that moral beliefs have a different constitution from non-moral beliefs. To put the point roughly, whilst non-moral beliefs are formed as a matter of sensitivity to brute aspects of the world, moral beliefs are cognitive states which are formed by a process of idealization of desires. It follows, for Smith, that the Pertinence Condition can then be met, because the further claims can still function to qualify or endorse the content of the beliefs expressed in the first-order claims in such a way as to make them amenable to talk of truth and objectivity. But it follows that the Independence Condition can also be met, since the further claims can be regarded, in that role, as stating an ambition for moral discourse-to represent the moral aspects of the world in ways which are analogous to the ways in which non-moral beliefs represent the non-moral aspects of the world-which goes unsatisfied, thus permitting the status sceptic to be a sceptic.

This picture is, I think, is exposed to a dilemma. On one horn of it, it is prone to an acute instability. If the kind of truth of which first-order moral claims admit is such as to support the denial that they can ever be true, then it would seem that the same claims can be described as both true (by the lights of the Pertinence Condition) and not true (by the lights of the Independence Condition). That cannot be a satisfactory state of affairs.

It may be replied that moral claims can be appraised for their possession of two non-rival types of truth, which are constituted by different standards. But this leads us to the other horn of the dilemma. If the Independence Condition is engaged by the failure of moral claims to meet the standards appropriate for non-moral beliefs, why does that amount to anything other than the concern that moral claims are not made true by morons? Dworkin will, quite rightly, be completely untroubled by the non-availability of this picture of moral truth. If this is the only way in which the status sceptic can satisfy the Independence Condition,

63 Dworkin, supra note 1, p. 54 and passim. 
then the Independence Condition was not worth trying to satisfy in the first place. It seems to me that there is little here for Dworkin to fear.

\section{IS DWORKIN A NATURALIST?}

Dworkin is certainly unhappy with the standard range of naturalist theories on offer. Most of his attention is paid to the Cornell realist variant of naturalism, as defended by Richard Boyd, Nicholas Sturgeon, and David Brink. He disparages these accounts for their attachment to the causal impact hypothesis and the causal dependence hypothesis. These accounts are also guilty, on Dworkin's view, of interpreting moral concepts as natural kind concepts, rather than as interpretive concepts. ${ }^{64}$

I tend to share Dworkin's reservations about these forms of naturalism. Even so, I believe there is intellectual pressure for Dworkin to accept some form of naturalism. Dworkin concedes that supervenience obtains in moral ascription: moral properties are instantiated in virtue of the descriptive properties which underlie or subvene them.65 That tends to suggest, at least as a first pass, that moral properties are strictly distinct from the non-moral properties which underlie them. ${ }^{66}$ And that leads, in turn, to the question of what moral properties are. Even if our guide to the existence and distribution of moral properties is to be provided exclusively by first-order moral argument, that

64 Ibidem, Part II, esp. ch. 8. Some may be inclined (as I am) to classify David Wiggins's and John McDowell's metaethical work as broadly naturalist, despite their occasional references to non-natural properties: Dworkin has his say about these theories in the endnotes: ibidem, pp. 441-446 (at n. 6).

65 Ibidem (manuscript at 86-87).

66 Perhaps moral properties can be reduced instead to natural properties, or to a disjunctive list of natural properties: see, for example, Jackson, Frank, From Metaphysics to Ethics: A Defence of Conceptual Analysis, Oxford, Oxford University Press, 1997, and Sturgeon, Nicholas, 'Doubts about the Supervenience of the Ethical', Oxford Studies in Metaethics, Volume Four, edited by R. Schafer-Landau, R., Oxford, Oxford University Press, 2009, for discussions of some of the relevant possibilities. But Dworkin is unwilling to pursue such questions. 
should not stop us from trying to achieve a more lucid characterization of moral properties than Dworkin is prepared to deliver in the following representative summary of his holistic, quietist approach:

What makes a moral judgment true? When are we justified in thinking a moral judgment true? My answer to the first [question]: moral judgments are made true, when they are true, by an adequate moral argument for their truth. Of course that invites the further question: what makes a moral argument adequate? The answer must be: a further moral argument for its adequacy. And so forth. 67

Let us agree with Dworkin that the property of goodness is properly ascribed through the resources of ordinary moral argument, and that goodness supervenes on the non-moral properties which serve as the evidence of goodness. We might then imagine someone asking, in a non-sceptical spirit, what kind of property goodness is. How can Dworkin deny this is a proper inquiry? Everything else, it would seem, can be metaphysically evaluated, so why not moral properties? For example, are moral properties continuous with the other inhabitants of the natural realm or do they constitute a departure from it? Are they sui generis, or are they to be subsumed under some broader metaphysical category? As Schafer-Landau suggests, these do not seem to be improper questions. They can be legitimately raised even if one thinks, with Dworkin, that the justification for moral claims must all be resolved within the compass of first-order theorizing.

So why is Dworkin so resistant to these questions? I think his underlying concern may be that if we were to pursue such questions, we would be creating undesirable hostages to fortune. I shall now attempt to enlarge on this suspicion. 
The following series of claims, which I collect together as the Hostages to Fortune View, presents a picture of moral theorizing which I think Dworkin wishes to reject:

\section{Hostages to Fortune View}

In pursuing moral arguments, we attempt to locate properties which, on a metaphysical realist picture, subvene moral properties. In other words, we locate, or attempt to locate, the good-making and bad-making properties of courses of action, institutions, practices and whatever else. The good-making properties of $X$ differ from the property of goodness itself. This suggests that the location of the good-making properties of $X$ leaves the job incomplete. For someone who wanted to know if $X$ is good, it is not enough to establish that $X$ has good-making properties; we will need a further argument to establish the presence of goodness in addition to the good-making properties.

If the Hostages to Fortune View, or something like it, is indeed the metaethical picture which Dworkin has in mind, I think he is right to find it unsatisfactory. 68 If we are leaving hostages to fortune at the point where we have supposedly established that $X$ has good-making properties, but is not (yet) good, then we are suggesting, in effect, that we do not yet know whether $X$ has any good-making properties. Here it needs to be noted that 'good-making' suggests a relation of determination: if $X$ has good-making properties, then it should follow that $X$ 's goodness is determined by its good-making properties.

So, if we have established the presence of good-making properties through applying the usual resources of first-order moral argument, we should not have to worry about the further presence of goodness itself. That should come along for the ride. Alternatively, if we have not yet established the presence of good-making properties, due to the fact that we

68 For some evidence that Dworkin has something like the Hostages to Fortune View in mind, see his remarks on the distinction between seeking evidence for (scientific) propositions and making a case for (moral) propositions: ibidem, pp. 114-117. 
have not yet established the presence of goodness, then the conclusions of the first-order moral arguments must be construed in a much weaker way. It is not the good-making properties of $X$ which we will have established, but something altogether much more hedged and conditional: we will have established only that $X$ has good-making-propertiesjust-as-long-as- $X$-has-the-property-of-goodness-in-additionto-what-would-seem-to-be- $X$ 's-good-making-properties. And this means, in turn, that we will have no choice but to construe ordinary moral arguments as being involved in a complicated division of labour, where the provisional or conditional conclusions established by those arguments must now await the sort of ratification which only metaethics can provide.

Contrary to what Dworkin seems to think, it does not follow from a principled opposition to the Hostages to Fortune View that we cannot or should not provide a metaphysical characterization of goodness. It suggests only that we cannot or should not tolerate a division of labour where our normative conclusions must then somehow await confirmation by moral metaphysics. It is the avoidance of metaphysical hostages to fortune, rather than the avoidance of metaphysics, which Dworkin has actually argued for, even if that truth does not seem to be wholly apparent to him.

Nothing Dworkin actually argues for, then, requires that a metaphysical characterization of moral properties must be deemed inappropriate. So why do I say that there is intellectual pressure on him to accept naturalism in particular? It is because naturalism is metaphysically tidy and epistemologically unproblematic, and requires no revision of the descriptivist parts of moral phenomenology. Naturalism offers us moron-free territory, and Dworkin is after moron-free territory.

I lack the space here to pursue, in a more fine-grained way, the question of which type of naturalism Dworkin should embrace. But in any case, there is no certainly no need for him to accept, as he most routinely does, that any 
version of naturalism is required to follow the example of Cornell realism and uphold the causal impact hypothesis and the causal dependence hypothesis. A naturalist metaethics can follow Dworkin's holistic approach to moral justification, and agree on the Pertinence Condition, whilst still having something to say about moral metaphysics.

There is some tentative evidence, in fact, at least in 'Objectivity and Truth', that Dworkin himself thinks that he might be able to accept the possibility of a naturalistic identification between moral properties and natural properties without capsizing the rest of his theory. ${ }^{69} \mathrm{He}$ does not pursue the issue, as he thinks that the line of argument he is considering cannot furnish morality with any external vindication. He is right about that, but wrong to think that the matter does not warrant his further attention. It warrants his attention because, as philosophers, we are entitled to know what moral properties are.

\section{CONCLUSION}

I submit, in conclusion, that Dworkin's opposition to the possibility of metaethical groundings shows much promise. But three caveats must be recorded.

First, Dworkin over-estimates the dialectical value of Hume's Principle, and the associated division between internal and external sceptical challenges. It is not Hume's Principle, but the Pertinence Condition, which is really doing all the heavy lifting for him.

Second, Dworkin's concern to avoid leaving metaphysical hostages to fortune is taken by him, rashly, to justify a principled incuriosity about moral metaphysics. But the arguments he deploys do not justify this incuriosity, and he should seek more lucid resolutions on questions of moral metaphysics than he has been prepared to pursue. (I have suggested, in this connection, that naturalism may fit the

69 Dworkin, 'Objectivity and Truth', supra note 4, pp. 99-101. 
bill. Perhaps Dworkin will refuse that invitation; still, his treatment should be sharpened in some way or other.)

Third, and as we have seen, the question of whether morality provides us with categorical reasons for action-the question which has rightly exercised such a huge influence over contemporary metaethics-is a question which Dworkin largely tenders out to the later parts of Justice for Hedgehogs. That is in no way objectionable, of course-it does not, in and by itself, generate a caveat-but it does mean that Dworkin's metaethical rivals need not fear for their futures until he has made good on these parts of his project. Dworkin's view seems to be that, as he emerges from the first two parts of Justice for Hedgehogs, metaethics is no longer a going concern. But that is not really the case. If the moral and conceptual impulses which have been poured into rival metaethical accounts cannot be properly rationalized within Dworkin's first-order holistic account, they will reappear elsewhere, and we will need to go back to the metaethical drawing-board in order to determine how our disappointed expectations about morality ought to be accommodated. So the stakes, for Dworkin, are very high. ${ }^{70}$

Even with these caveats to take on board, Dworkin's arguments are deeply powerful and suggestive, and it seems to me that there is everything to play for. Quietism is in with a shout. 71

70 But might the existence of categorical moral reasons not raise awkward metaphysical issues? Again, these reasons will not be made true by moron-like truth-makers, but we may still require a greater level of metaphysical resolution than Dworkin is prepared to provide. See also Scanlon, T. M., Being Realistic About Reasons, 2009 John Locke Lectures, unpublished manuscript, for a detailed discussion of the relevant options.

71 Thanks to Daniel Elstein, Andy McGonigal, and Cain Todd for helpful conversations about these issues. 